Provided for non-commercial research and education use. Not for reproduction, distribution or commercial use.

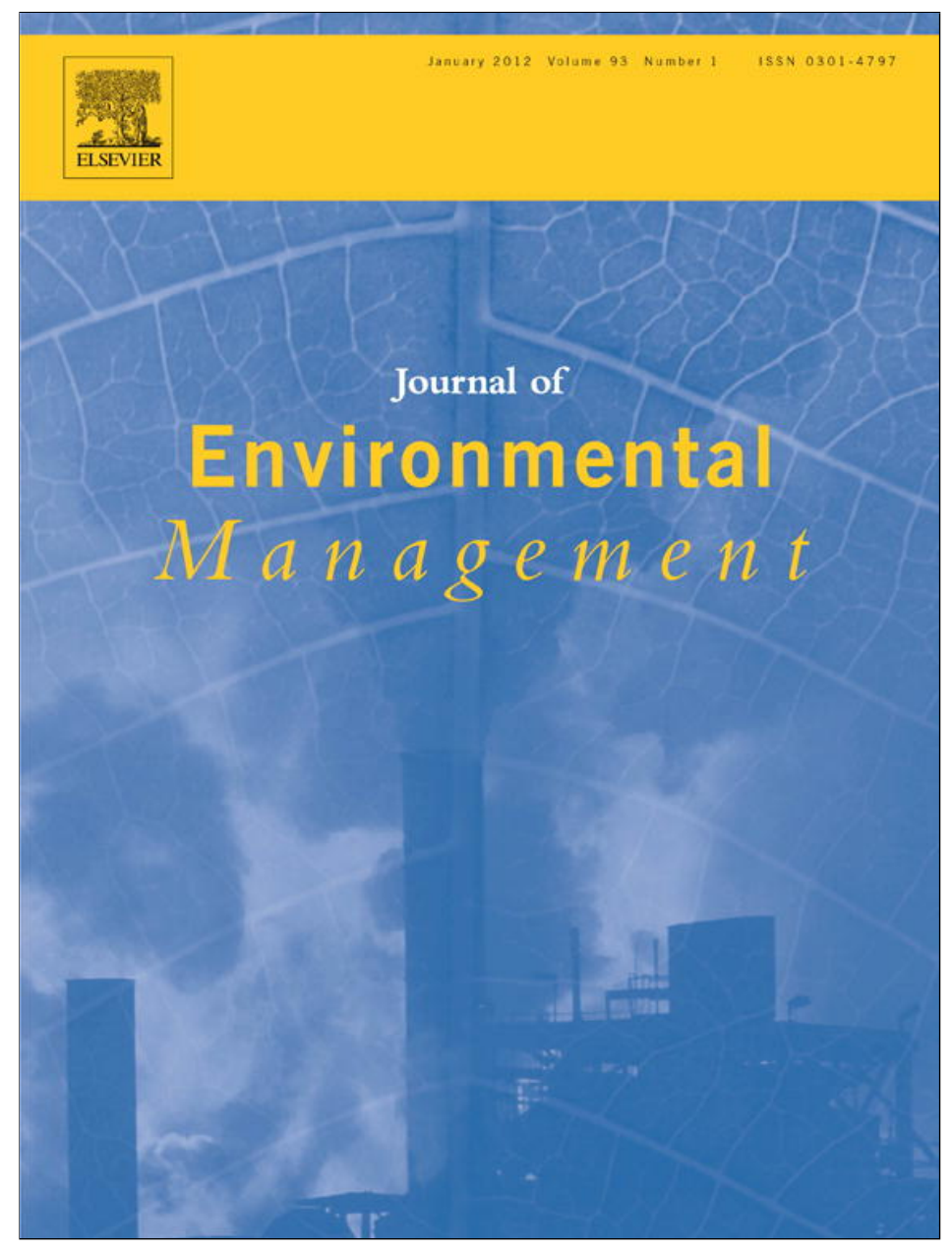

(This is a sample cover image for this issue. The actual cover is not yet available at this time.)

This article appeared in a journal published by Elsevier. The attached copy is furnished to the author for internal non-commercial research and education use, including for instruction at the authors institution and sharing with colleagues.

Other uses, including reproduction and distribution, or selling or licensing copies, or posting to personal, institutional or third party websites are prohibited.

In most cases authors are permitted to post their version of the article (e.g. in Word or Tex form) to their personal website or institutional repository. Authors requiring further information regarding Elsevier's archiving and manuscript policies are encouraged to visit:

http://www.elsevier.com/copyright 
Review

\title{
Three centuries of managing introduced conifers in South Africa: Benefits, impacts, changing perceptions and conflict resolution
}

\author{
Brian W. van Wilgen ${ }^{\mathrm{a}, *}$, David M. Richardson ${ }^{\mathrm{b}}$ \\ ${ }^{a}$ Centre for Invasion Biology, CSIR Natural Resources and the Environment, P.O. Box 320, Stellenbosch 7599, South Africa \\ ${ }^{\mathrm{b}}$ Centre for Invasion Biology, Department of Botany and Zoology, Stellenbosch University, Private Bag X1, Matieland 7602, South Africa
}

\section{A R T I C L E I N F O}

\section{Article history:}

Received 30 May 2011

Received in revised form

3 March 2012

Accepted 26 March 2012

Available online $\mathrm{xxx}$

\section{Keywords:}

Biodiversity

Biological invasions

Fire

Forestry

Hydrology

Land-use

Pinus

\begin{abstract}
A B S T R A C $T$
Alien conifers, mainly pines, have been planted in South Africa for a range of purposes for over 300 years. Formal plantations cover 660000 ha of the country, and invasive stands of varying density occur on a further 2.9 million ha. These trees have brought many benefits but have also caused unintended problems. The management of alien conifers has evolved in response to emerging problems such as excessive water use by plantations of conifers, changing values and markets, and the realities of a new ecological order brought about by invasive alien conifers. This paper reviews the history of conifer introductions to South Africa, the benefits and impacts with which they are associated, and the ongoing and evolving research that has been conducted to inform their management. The South African approach has included taking courageous steps to address the problem of highly invasive species that are also an important commercial crop. These interventions have not, however, had the desired effect of both retaining benefits from formal plantations while simultaneously reversing the trend of growing impacts associated with self-sown invasive stands. We suggest that different approaches need to be considered, including the systematic phasing out of commercial forestry in zones where it delivers low returns, and the introduction of more effective, focussed and integrated, region-specific approaches to the management of invasive stands of conifers. These steps would deliver much improved economic outcomes by protecting valuable ecosystem services, but will require political commitment to policies that could be unpopular in certain sectors of society.
\end{abstract}

(c) 2012 Elsevier Ltd. All rights reserved.

\section{Introduction}

Ecosystems provide people with a range of benefits, and the pressure on ecosystems to deliver these goods and services on a sustainable basis continues to mount as human populations grow (Millennium Ecosystem Assessment, 2005). Ecosystem managers are expected to oversee and advise on the implementation of a variety of interventions that will enhance the delivery of ecosystem services, while at the same time minimising risks to ecosystem integrity. These endeavours take place in an environment of incomplete knowledge of the functioning of complex social-ecological systems (Levin, 2002), and a paucity of models that can be used to predict the outcomes of interventions. In addition, ongoing and accelerating changes, brought about by land transformation and degradation, pollution, and ever-increasing

\footnotetext{
* Corresponding author. Tel.: +27 21888 2400; fax: +27 218882693.

E-mail addresses: bvwilgen@csir.co.za (B.W. van Wilgen), rich@sun.ac.za (D.M. Richardson).
}

demands for access to key resources provide a highly dynamic backdrop to the already complex challenge of effective ecosystem management. There are few examples of comprehensive attempts to address particular aspects of ecosystem management, or assessments of how such attempts have fared.

The widespread afforestation of landscapes with alien trees, in an attempt to provide timber and other benefits, is an example of a typical intervention that seeks to improve ecosystem service delivery. In South Africa, natural forests are rare, and cover only $8 \%$ of the land surface (FAO, 2010). Fast-growing conifers were introduced into southern Africa following European colonization in the 1650 s, and have become a dominant feature of many landscapes in the region. Conifers, particularly pines (species in the genus Pinus) are important to a modest (by global standards) forest industry that has been established largely in the fynbos (Mediterranean shrubland) and grassland areas where mean annual rainfall exceeds $800 \mathrm{~mm}$, and on land that is generally unsuitable for other forms of agriculture. This plantation-based forest industry has brought many benefits, and makes an important contribution to the country's economy. However, the establishment of these plantations has 
not been without cost. Pine plantations increase evapotranspiration and decrease streamflow (van Lill et al., 1980; van Wyk, 1987). In addition, pine species have become invasive, spreading significantly beyond the borders of formal plantations, and impacting negatively on surface water runoff, grazing resources and biodiversity, and exacerbating the problem of wildfires (Richardson, 1998; van Wilgen et al., 2008). These impacts have spawned conflict between foresters and conservationists, and have led to the development and evolution of novel approaches to the management of conifers in South Africa. This paper reviews research to improve understanding of introduced conifers, and to inform management policies and approaches. We document briefly the known benefits and negative impacts associated with conifers, and describe the development of policy intended to enhance benefits and to minimise impacts. We review the outcomes of these interventions, and identify possible future management options that would lead to improved ecological and economic outcomes.

\section{The introduction and spread of alien conifers in South Africa}

The introduction of alien conifer species to South Africa began with European colonization in the mid-seventeenth century. Early introductions were made for a range of reasons, including providing a source of timber, and an urge to "alter, tame or improve" landscapes (Richardson et al., 1997). Plantings were initially haphazard, but the organised establishment of formal plantations began in earnest in the early twentieth century. The expansion of conifer-based plantation forestry had a focus on pines (species in the genus Pinus, see Table 1), although other coniferous genera were planted, including species of Abies, Agathis, Araucaria, Cedrus, Cryptomeria, Cupressus, Picea, Pseudotsuga and Sequoia (Poynton, 2009). A number of small plantations of some species (for example Cupressus lusitanica and Sequoia sempervirens) were established in South Africa, but only pines were extensively planted. During the 1930s, government-sponsored schemes hired unemployed people to afforest large areas (mainly in the southern and southwestern coastal areas). Initially, plantation-based forestry was a government undertaking, but privately-owned plantations expanded in the middle to late 20th century. The area under formal afforestation with conifers (almost exclusively pines) reached a peak of 798000 ha in 1997, and then declined to 660000 ha in 2009 (Forestry South Africa, 2011).

As is the case in many other parts of the world where pines have been planted for forestry outside their native ranges (Richardson and Higgins, 1998; Richardson and Rejmánek, 2004; Richardson, 2006; Simberloff et al., 2010), the spread of pines from plantations into surrounding vegetation has become a widespread environmental problem in South Africa. In South Africa, pines began to spread from planting sites, invading natural vegetation, shortly after they were introduced (Richardson and Higgins, 1998), although concerns about invasions only began to emerge in the early 20th century (Stirton, 1978; van Wilgen, 2009). Pines are preadapted to fire-prone environments and have flourished, especially in fynbos vegetation (Mediterranean-climate shrubland). Despite considerable attempts to clear invasive pines in the late 20th and early 21 st centuries, the area covered by invasive pines has continued to grow. In 1996 it was estimated that invasive pine trees covered approximately 77000 ha of South Africa (Le Maitre et al., 2000) (areas are expressed as the equivalent of closed canopy stands). A more recent study (Kotzé et al., 2010) estimated that 130000 ha (equivalent closed canopy) were invaded. Although these estimates are crude, they suggest that invasions are increasing despite substantial efforts to keep them in check. Invasive pines now dominate many landscapes (Fig. 1), and are likely to become much more widespread if current trends continue (Rouget et al., 2004).

\section{Research as a basis for policy development}

\subsection{Finding the best species}

Forestry, and the establishment of plantations of conifers in South Africa, is based on a long tradition of research (Loock, 1950; Grut, 1965; Poynton, 1979). For example, Loock (1950) reported on detailed reconnaissance of Mexico and the British Honduras during 1947, in which he documented the indigenous pine species of the region, and made detailed recommendations regarding 19 species deemed to be worthy of importation for afforestation or ornamental purposes. A committee, established in 1948, was tasked with a systematic review of plantings of pines and other conifers in South Africa, with a view to establishing which species, and races, were best suited to particular areas (Poynton, 1979). This committee placed "great importance" on the classification of climates of southern Africa, and the development of a map of silvicultural zones as a basis for the rational interpretation of the results of planting trials that went back over 100 years in some cases. This work led to detailed recommendations on the relative suitability of planting for a range of purposes for 57 "major" species of pines (Table 1), and 11 "minor" species (a further nine species were considered to have been failures in terms of their suitability for planting in the country). While this work had the primary goal of optimising timber yields, it also ensured that species with the best chance of survival, vigorous growth, and invasive potential were planted most extensively in areas that matched their potential.

\subsection{Investigating environmental impacts}

Extensive droughts in the early 1930s led to concerns over the potential impacts of afforestation on water supplies. This issue was discussed during the Fourth Empire Forestry Conference hosted in South Africa in 1935. It led to the establishment, in 1936, of a programme of hydrological research aimed at determining "how normal afforestation, as carried out in state plantations, would affect climate, water conservation and erosion" (Wicht, 1939). The experimental design was based on paired catchments, some of which were afforested, while others were maintained as controls. Catchments were established at Jonkershoek in the Western Cape (afforested with Pinus radiata in 1936), at Cathedral Peak in the KwaZulu-Natal Drakensberg (afforested with Pinus patula in 1946), and at Mokubulaan in Mpumalanga (afforested with P. patula in 1956). This work revealed the relationships between afforestation and streamflow runoff, and led to the subsequent restriction of plantings (see 6.2 below).

\subsection{Assessing the ecology of invasive species}

The first record of naturalized and invasive pines in South Africa (and the southern hemisphere; Richardson and Higgins, 1998) is from 1855 - for Pinus halepensis in the Caledon district (Lister, 1959). Concerns that invasive alien plants (including pines) could pose serious threats to natural vegetation in South Africa were raised as early as the 19th century by botanists, including Harry Bolus in 1886, Peter MacOwan in 1888, and Rudolf Marloth in 1908 (Stirton, 1978). By 1977, however, predictions were being made that invasions would impact on water resources as well as biodiversity, based on comparisons of the effects of afforestation with pines, and comparison to analogous invasions of nearby areas by Pinus pinaster (Kruger, 1977). The need for a better understanding of the 
Table 1

Dates of introduction, extent of planting and invasive status or potential for the major species of pines in South Africa. Dates of introduction and extent of planting after Poynton (1979); invasive status from Henderson (2001). Fischer's Z-statistic provides an indication of invasive potential; positive values are associated with invasive species, and negative values with non-invasive species; data from Rejmánek and Richardson (1996). Species with low Z-scores are invasive sometimes, but then only in cases where the species have been widely planted over a long time; see Richardson and Rejmánek (2004) and Richardson (2006) for discussion. Species listed as "declared invaders in category 2 in South Africa" are recognised weeds that also have commercial value; see Section 6.4 in text.

\begin{tabular}{|c|c|c|c|}
\hline Pinus species & Date of first introduction & Extent of planting prior to 1979 & Invasive status (Fischer's Z-score in brackets) \\
\hline P. arizonica & 1907 & Fairly widespread but limited planting & Potentially invasive (1.5). \\
\hline P. attenuata & 1884 & Localised and limited planting & Potentially invasive (1.1). \\
\hline P. ayacahuite & 1906 & Localised and limited planting & Potentially highly invasive (8.7). \\
\hline P. banksiana & 1902 & Very localised and limited planting & Potentially highly invasive (8.7). \\
\hline P. canariensis & 1878 & $\begin{array}{l}\text { Widespread, established in plantations } \\
\text { where it is of minor importance ( } 3500 \text { ha) }\end{array}$ & $\begin{array}{l}\text { Recorded as invasive in Australia and South Africa, but only } \\
\text { very near plantations and is only mildly invasive. Declared } \\
\text { invader in category } 2 \text { in South Africa }(-1.8) \text {. }\end{array}$ \\
\hline P. caribaea & 1927 & Localised and limited planting & Potentially invasive (1.3). \\
\hline P. cembroides & 1902 & Localised and limited planting & Not potentially invasive $(-10.4)$ \\
\hline P. clausa & 1969 & Very localised and limited planting & Potentially highly invasive (11.5) \\
\hline P. contorta & 1902 & Very localised and limited planting & Potentially highly invasive (12.3) \\
\hline P. cooperi & 1907 & Very localised and limited planting & Unknown \\
\hline P. coulteri & 1894 & Very localised and limited planting & Not potentially invasive $(-3.7)$. \\
\hline P. cubensis & 1949 & Very localised and limited planting & Unknown \\
\hline P. densiflora & 1893 & Very localised and limited planting & Potentially invasive (2.0) \\
\hline P. douglasiana & 1908 & Very localised and limited planting & Unknown \\
\hline P. echinata & 1899 & Localised and limited planting & Potentially highly invasive (5.6). \\
\hline P. elliottii & 1916 & Widespread, established in plantations (134 000 ha) & $\begin{array}{l}\text { Known invasive. Declared invader in category } \\
2 \text { in South Africa. (4.33). }\end{array}$ \\
\hline P. engelmannii & 1907 & Widespread and limited planting & Not potentially invasive. $(-5.0)$ \\
\hline P. flexis & 1902 & Very localised and limited planting & Not potentially invasive. $(-4.1)$ \\
\hline P. gerardiana & 1907 & Very localised and limited planting & Not potentially invasive. $(-13.7)$. \\
\hline P. greggii & 1910 & Localised and limited planting & Unknown \\
\hline P. halepensis & 1850 & Widespread and limited planting & $\begin{array}{l}\text { Highly invasive in many parts of the world. Declared } \\
\text { invader in category } 2 \text { in South Africa (9.2) }\end{array}$ \\
\hline P. hartwegii & 1907 & Very localised and limited planting & Unknown \\
\hline P. jeffreyi & 1900 & Very localised and limited planting & Potentially invasive (2.4). \\
\hline P. kesiya & 1906 & Widespread and limited planting & Potentially highly invasive (11.0). \\
\hline P. koraiensis & 1901 & Very localised and limited planting & Not potentially invasive $(-9.9)$ \\
\hline P. lambertiana & 1890 & Very localised and limited planting & Not potentially invasive $(-15)$. \\
\hline P. lawsonii & 1907 & Very localised and limited planting & Unknown \\
\hline P. leiophylla & 1908 & Widespread and limited planting & Not potentially invasive $(-3.1)$. \\
\hline P. luchuensis & 1932 & Very localised and limited planting & Unknown \\
\hline P. lumholtzii & 1912 & Very localised and limited planting & Unknown \\
\hline P. massoniana & 1894 & Localised and limited planting & Unknown \\
\hline P. merkusii & 1904 & Localised and limited planting & Potentially highly invasive (5.8). \\
\hline P. michoacana & 1906 & Very localised and limited planting & Unknown \\
\hline P. montezumae & 1858 & Localised and limited planting & Unknown \\
\hline P. muricata & 1894 & Localised and limited planting & Potentially highly invasive (10.0). \\
\hline P. nigra & 1883 & Very localised and limited planting & Potentially invasive (1.8). \\
\hline P. oocarpa & 1911 & Very localised and limited planting & Unknown \\
\hline P. palustris & 1884 & Localised and limited planting & Not potentially invasive $(-6.4)$ \\
\hline P. patula & 1907 & Widespread, established in plantations (268 000 ha) & $\begin{array}{l}\text { Known invasive. Declared invader in } \\
\text { category } 2 \text { in South Africa (8.2) }\end{array}$ \\
\hline P. pinaster & $\sim 1690$ & Widespread, established in plantations (35 $000 \mathrm{ha}$ ) & $\begin{array}{l}\text { Known invasive. Declared invader in } \\
\text { category } 2 \text { in South Africa (8.3). }\end{array}$ \\
\hline P. pinea & $\sim 1750$ & Localised and limited planting & Not invasive $(-15.5)$ \\
\hline P. ponderosa & 1894 & Widespread and limited planting & Potentially invasive (0.7). \\
\hline P. pringlei & 1907 & Localised and limited planting & Unknown \\
\hline P. pseudostrobus & 1908 & Widespread and limited planting & Unknown \\
\hline P. radiata & $\sim 1835$ & Widespread, established in plantations (51 $000 \mathrm{ha}$ ) & $\begin{array}{l}\text { Known invasive. Declared invader in } \\
\text { category } 2 \text { in South Africa (10.1). }\end{array}$ \\
\hline P. rigida & 1865 & Localised and limited planting & Potentially invasive (3.6). \\
\hline P. roxburghii & 1865 & Widespread, established in plantations (2500 ha) & $\begin{array}{l}\text { Not aggressively invasive. Declared } \\
\text { invader in category } 2 \text { in South Africa }(-1.3) \text {. }\end{array}$ \\
\hline P. sabriana & 1894 & Very localised and limited planting & Not aggressively invasive $(-8.9)$ \\
\hline P. serotina & 1958 & Very localised and limited planting & Potentially highly invasive (12.7). \\
\hline P. strobus & $\sim 1890$ & Very localised and limited planting & Potentially invasive (5.0). \\
\hline P. sylvestris & $\sim 1670$ & Widespread and limited planting & Potentially highly invasive (10.2). \\
\hline P. taeda & $\sim 1880$ & Widespread, established in plantations (47 $000 \mathrm{ha}$ ) & $\begin{array}{l}\text { Known invasive. Declared invader in } \\
\text { category } 2 \text { in South Africa (2.8). }\end{array}$ \\
\hline P. tenuifolia & 1910 & Very localised and limited planting & Unknown \\
\hline P. teocote & 1948 & Very localised and limited planting & Unknown \\
\hline P. thunbergii & 1898 & Very localised and limited planting & Potentially highly invasive (10.4). \\
\hline P. tropicalis & 1948 & Very localised and limited planting & Unknown \\
\hline P. wallichiana & 1865 & Widespread and limited planting & Potentially invasive (1.2). \\
\hline
\end{tabular}



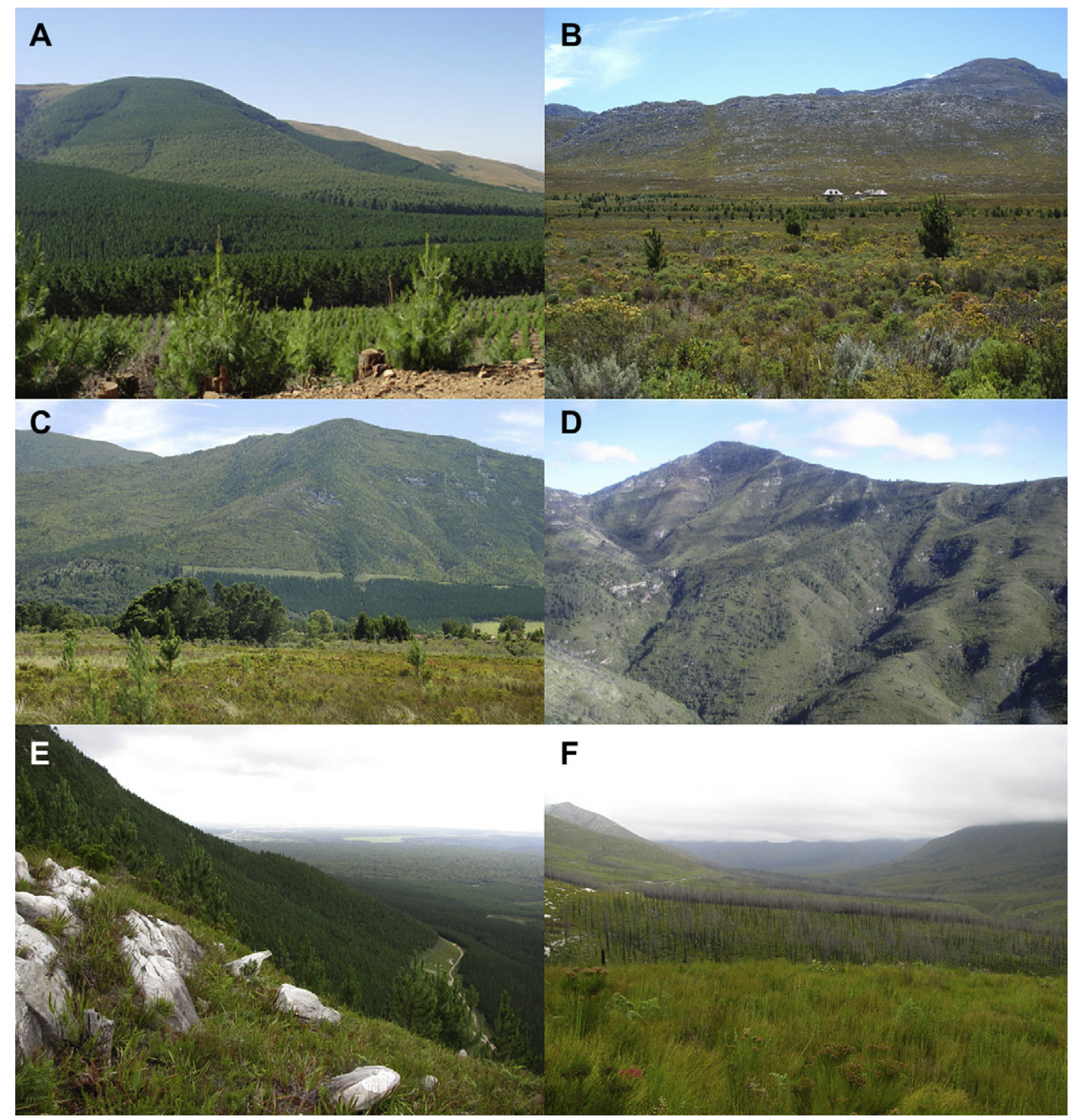

Fig. 1. Alien pines in different settings in South Africa. A: plantations of Pinus patula established in grassland in Mpumalanga Province; B: scattered invasive pines in fynbos vegetation in the Western Cape; C: Plantation of Pinus radiata and associated invasions in adjacent fynbos in the Eastern Cape Province; D: Remote and rugged mountains invaded by Pinus pinaster and P. radiata in the Eastern Cape Province; E: Dense invasions of Pinus radiata above a plantation (below the firebreak) in the Eastern Cape Province; F: Abandoned (uneconomic) plantation that has subsequently burnt in a wildfire in the Eastern Cape Province.

problem led to increased research into the ecology and control of invasive species (see, for example, Fugler, 1979; Richardson, 1989). This research received a boost with the establishment of the SCOPE programme on the ecology and management of invasive species in 1982, which led to a synthesis of knowledge (Macdonald et al., 1986) and a growing recognition of the importance of the problem of biological invasions.

\subsection{Predicting the environmental and economic impacts of invasions}

In the mid-1990s, ecologists developed models of the spread and impact of invading pine trees on water resources, by combining ecological and hydrological understanding (Le Maitre et al., 1996; 2002; van Wilgen et al., 1996). These models simulated the spread of invasive alien trees (mainly pines) and shrubs into fire-prone fynbos ecosystems. Pines are killed by fire, and they regenerate and spread from seeds released after fires. The occurrence of fires was used to trigger plant spread in the models, which produce estimates of the extent of infestations, and the growth of the plants between fires. The models further estimated the impacts of these invasions on streamflow, based on the assumption that invasions by pines would have similar impacts to those measured in afforestation experiments. The predictions made by this research were used to motivate significant government investment into alien plant control programs (van Wilgen et al., 2011a).

Further impacts associated with pine plantations (and pine invasions) were investigated opportunistically as a result of wildfires in the afforested experimental catchments at Jonkershoek and Cathedral Peak (Scott et al., 1998; Scott and van Wyk, 1990; van Wyk, 1985). The work sought to quantify the combined impacts of afforestation and fire on soil erosion, and provided further evidence of the detrimental impacts of both afforestation and invasions when they are combined with (essentially inevitable) wildfires.

More recently, research has sought to quantify the impacts of invasive species in monetary terms, as a basis for comparison with the benefits generated by species that both bring benefits and do 
harm (De Wit et al., 2001). De Lange and van Wilgen (2010) estimated that the loss of ecosystem services (mainly water) attributable to "fire-adapted trees" (mainly pines) in the fynbos biome alone was two billion rands annually at current levels of infestation (1 US\$ = approximately 7 South African rands).

\subsection{Developing sustainable control methods}

The recognition that invasive pines could have serious environmental impacts led to the initiation in the late 1990s of a research project aimed at the biological control of invasive pine species (Moran et al., 2000). The emphasis was on the use of seedand cone-feeding insect and mite agents: (i) because seed reduction has the potential of decreasing the invasiveness of alien plants; (ii) because of the problem of re-growth of the trees, mainly from seeds, in areas previously cleared; and (iii) because the exclusive use of seed- and cone-destroying agents may lessen conflict between the main role players, namely, conservationists, on the one hand, and the forestry industry, on the other. The program led to the identification of at least one suitable agent (the cone-feeding weevil Pissoides validirostris on P. pinaster). However, after a decade of research, it was decided not to proceed with this work (Lennox et al., 2009). Although the beetles were found to be suitably specific in their breeding behaviour and only utilise cones of P. pinaster for this purpose, the adult beetles did feed on the stems of other pine species during autumn. This type of damage has no direct detrimental effect on the plants, but, under laboratory conditions, the wounding allows ingress of the fungal pathogen known as pine pitch canker, Fusarium cincinatum, which is a major pathogen of pines (Richardson et al., 2007). Reasonable arguments could be presented to show that the beetles would probably not aggravate the prevalence of pitch canker under field conditions, but no guarantees could be given. In the light of these findings, together with the uncertainty that currently surrounds pitch canker in South Africa, the research was suspended, reflecting a very conservative approach to risk. However, because the estimated impacts of invasive pines substantially exceed benefits generated by pinebased plantation forestry (see Section 4.1), and because biological control offers the only really effective, long-term, sustainable solution to the problem, this decision is likely to be reviewed (Hoffmann et al., 2011).

\section{The benefits of alien conifers}

\subsection{Plantation forestry}

The major benefits from conifers in South Africa come from the forest industry. This industry has established plantations of alien pines (mainly $P$. patula in the summer-rainfall areas, and $P$. radiata in winter-rainfall areas) that covered 660000 ha in 2009. These conifers account for more than half (54.1\%) of the total area of forest plantations in the country. The industry as a whole supports 211 processing plants, ranging from small sawmills to large pulp mills which collectively process 8.1 million $\mathrm{m}^{3}$ of conifer timber annually. Exports from the forest industry amount to R9.5 billion (US\$ 1.3 billion) annually, and include solid wood (37\%), pulp (35\%) and paper (28\%). The industry employs over 75000 people directly, while associated activities that depend on forestry employ a further 30000 people; in a country with high levels of unemployment (>20\%), this is an important contribution (data from Forestry South Africa, 2011).

It is, however, necessary to distinguish between benefits derived from pine-based plantation forestry in fynbos shrublands, and those elsewhere in South Africa (see also sections 8.1 and 8.3). Only $5.8 \%$ of plantations are in the fynbos biome ( $87 \%$ pines), generating
R146 million in roundwood sales in 2009 (www.forestry.co.za). Many of these plantations are not economically viable (see Section 7.3). On the other hand, the loss of ecosystem services attributable to invasive pines in the fynbos biome was estimated at R2 billion annually at current levels of infestation (De Lange and van Wilgen, 2010). These impacts will increase as infestations spread and become denser.

\subsection{Carbon sequestration}

Tree plantations are often promoted as a means of carbon sequestration, because of the increases in plant biomass that they bring about (see, for example, Wright et al., 2000). In South Africa, the afforestation or invasion of native grasslands and fynbos shrublands with alien conifers can significantly increase above-ground biomass (from 1000 to $5000 \mathrm{~g} \mathrm{~m}^{-2}$ in native vegetation to 5000-25 $000 \mathrm{~g} \mathrm{~m}^{-2}$, Versfeld and van Wilgen, 1986). However, the capacity for South African landscapes to support sufficient plantations to offset carbon emissions is low. For example, a doubling of South Africa's plantation forest area by 2030 will offset $<1 \%$ of greenhouse gas emissions, estimated to be approximately $450000 \mathrm{Gg} \mathrm{CO} 2$ equivalent per year in South Africa in 2000 (Anonymous, 2009). In addition, such an expansion of plantation area would have considerable costs in terms of substantial losses in streamflow, and increased soil salinization and acidification (Jackson et al., 2005), and will have major impacts on biodiversity. Because of high levels of water use (see Section 5.1), and low potential impact, plantation forestry is not currently seen as an appropriate mechanism for offsetting carbon emissions in southern Africa.

\subsection{Aesthetic benefits}

Alien conifers bring aesthetic and recreational benefits. Many people find trees aesthetically pleasing, and the establishment of trees in an environment where they were naturally rare, or were severely depleted by early colonists for timber, was the original motivation for the importation of many tree species, including conifers. Many plantation areas are also heavily utilised by urban people for recreation (picnicking, cycling, walking), mainly because of the shade that they provide. There are no estimates of the value of these benefits, but attempts to remove pines where they border on urban areas are often met with strong resistance (van Wilgen, in press).

\subsection{Conservation}

Several coniferous species that are utilized globally in plantation settings are rare and/or endangered in their native ranges. The Central America and Mexico Coniferous Resources Cooperative (CAMCORE) was established in 1980, with the goal of identifying threatened tree species and provenances, collecting seeds from these vulnerable populations, and distributing seeds for ex situ conservation and growth studies (www.camcore.org; accessed 6 May 2011). CAMCORE is a leading player in this field in South Africa, and all of the major growers are members. CAMCORE makes seed collections in threatened forest stands and then plants these on its member's land in more protected areas with similar climates in countries around the world. Several such plantations have been established in South Africa, where they are seen as part of a global effort to conserve forest resources. The plight of $P$. radiata, which has a very limited natural range in California, provides a good example. The species has suffered dramatic declines in its native range through the introduction of alien diseases (Richardson et al., 2007), and the potential exits to re-introduce the species from translocated populations, once resistance to the disease has been achieved. 


\section{Impacts associated with alien conifers}

\subsection{Conifers and water use}

Reductions in surface water runoff have been foremost among the impacts associated with pines in South Africa (Görgens and van Wilgen, 2004). As a general rule, trees tend to use more water than grasses or shrubs (Bosch and Hewlett, 1982; Dye, 1988, 1996; Jackson et al., 2005; Smith and Scott, 1992), and the greatest impacts occur when seasonally dormant vegetation is replaced by evergreen plants (Dye et al., 1995). Thus, where grasslands or shrublands are replaced by either plantations or self-sown stands of invasive trees, vegetation water use increases, and runoff decreases. Much of the evidence for this statement comes from catchment experiments in South Africa. These experiments were established in high-rainfall areas where shrublands or grasslands were converted to plantation forestry. Typical examples of results include an $82 \%$ reduction in streamflow (reductions of 115 and $640 \mathrm{~mm}$ rainfall equivalent/yr in two small grassland catchments) 20 years after planting with pines (Bosch, 1979); a 55\% reduction in streamflow (from 600 to $270 \mathrm{~mm}$ rainfall equivalent/yr) in fynbos catchments 23 years after planting with pines (van Wyk, 1987); and the total drying up of streams 6-12 years after completely replacing grassland catchments with pines and eucalypts (van Lill et al., 1980). By combining models of fire and plant spread with the above understanding of hydrological impacts, Le Maitre et al. (1996) estimated that the cover of invasive pines would increase from $2.4 \%$ to $62.4 \%$ over the next 100 years in one of the major catchment areas that supplied the water needs of the nearby city of Cape Town. This would in turn lead to an average annual reduction of $347 \mathrm{~m}^{3}$ of surface water runoff per ha (a $100 \mathrm{~mm}$ rainfall equivalent reduction in runoff equates to $1000 \mathrm{~m}^{3} /$ ha), equivalent to $30 \%$ of the water supply of the city of Cape Town.

\subsection{Conifers and fire severity}

Afforestation or invasion by conifers increases biomass, fuel loads and fire intensity. Typical fuel loads in grass and shrublands are around 0.3-4 tonnes/ha (van Wilgen and Scholes, 1997), while planted or invaded sites have significantly more fuel (10-25 tonnes/ha, van Wilgen and Richardson, 1985). While ecosystems in South Africa are normally quite resilient to regular burning, these increased fuel loads lead to higher intensity fires and a range of detrimental effects. Physical damage to the soil can occur, resulting in increased erosion after fire. For example, six tonnes of soil/ha was lost following fires in pine stands compared to 0.1 tonnes/ha following fire in adjacent fynbos in the Western Cape (Scott et al., 1998); and 37 tonnes/ha was lost following fires in pine stands compared to 1.8 tonnes/ha in adjacent grassland in the KwaZulu-Natal Drakensberg (Scott and van Wyk, 1990; van Wyk, 1985). The increasing density and extent of invasion by pines in an environment where wildfires are regular and extensive (van Wilgen et al., 2010) has led to a growing problem of soil instability and erosion, especially in the fynbos (Mediterranean-climate shrubland) vegetation typical of the southwestern regions of the country (van Wilgen and Scott, 2001).

\subsection{Conifers and native biodiversity}

The afforestation or invasion of pristine ecosystems will impact negatively on native species density, and can lead to the local or total extinction of species. While the nature and extent of the impacts of invasive species on ecosystem structure and composition are poorly documented (Richardson and van Wilgen, 2004), alien species are known to be a major threat to native plant species.
The status of southern African plant species has been more thoroughly assessed than anywhere else in the world. Of 20456 known plant species in the region, about $15 \%$ are listed as extinct, endangered or threatened (Raimondo et al., 2009). Of these, the extinction of 7 species has been attributed primarily or wholly to invasive alien species, and a further 1207 species are threatened at least in part by to invasive alien species. Transformation of landscapes by forestry plantations in Mpumalanga province has reduced the populations of 90 bird species, almost half of them being threatened endemics (Allen et al., 1997). The loss of keystone species is of particular concern. Examples include the $5 \%$ of plants (430 species) in the Cape Floral Kingdom that are pollinated by birds (if eight key bird species disappear through habitat elimination by invading alien plants or other causes, it would impact on 430 plants, and on many insects and other species dependent on those plants, Johnson, 1992). These are typical cascade effects which will become more evident as alien organisms replace natural communities. Pryke and Samways (2009) found that invertebrate communities in pine plantations had low species richness and abundance in comparison to surrounding areas, and concluded that their study strongly supported the removal of pines in an urban setting. Conversely, the clearing of stands of invasive trees along rivers has been shown to result in the re-appearance of dragonflies that were previously assumed to have been extinct (Samways et al., 2005). Biodiversity impacts will be most keenly felt in the fynbos (Mediterranean-climate shrublands), which cover $90000 \mathrm{~km}^{2}$ of southwestern South Africa. This area, $4 \%$ of the land surface of southern Africa, contains $45 \%$ of the subcontinent's plant species. There are almost 8600 species of flowering plants and ferns, of which almost $70 \%$ (5850 species) are endemic (Bond and Goldblatt, 1984). Almost one third of the fynbos biome has already been transformed by urbanization, agriculture and forestry (van Wilgen, 1988), and the remaining areas (mainly in the mountains) are under severe threat from invading alien plants, of which pines are one of the main taxa (Rouget et al., 2003).

\section{Policy responses}

\subsection{Forest policy environment}

The South African institutional framework for environmental management is divided and dynamic. There are national government departments responsible for water, for forestry, for agriculture, and for the environment, with overlapping responsibilities. In addition, departments and their responsibilities have been merged and/or split in the past. Here we focus on legislation that affects forestry and invasive species, which has evolved over the past century in response to changing needs, circumstances, values and understanding. In the late 19th and early 20th century, forestryrelated legislation sought largely to encourage the planting of alien trees, and to protect forest resources, for example from fire (Richardson et al., 2003; Olivier, 2009). Much of the tree-planting was subsidised by the government of the day to provide a supply of wood (a strategic resource) and to create employment. With the realization that plantation forestry was responsible for significant reductions in streamflow, amendments to the legislation in 1972 consequently sought to restrict afforestation (see Section 6.2). As private-sector plantation forestry grew, the government's ongoing role in commercial forestry became questionable, and a process of privatization of state-owned plantations was initiated in the late 1980s. More significant changes came with the inauguration of South Africa's first democratically-elected government in 1994. These included the need for payments for streamflow reduction under the new Water law (National Water Act, Act 36 of 1998), as well as requirements to take responsibility for, and to combat the 
spread of, invasive trees from plantation environments (see Section 6.4 below).

\subsection{Putting a limit on afforestation}

The demonstrated impacts of afforestation with pines and other trees on streamflow led to the introduction of restrictions on new plantings in order to conserve water resources in 1972. These restrictions were formulated in terms of an amendment to the existing forest act (Forest Amendment Act, Act 40 of 1972), in terms of which an afforestation permit system was established (van der Zel, 1995). Watersheds were classified as either category 1 (where water demand was greatest, and no further afforestation would be allowed), category 2 (where sporadic water shortages were envisaged, and new afforestation was restricted reducing mean annual surface water runoff by $<5 \%$ ), and category 3 (where reductions in mean annual surface water runoff of up to $10 \%$ were allowed). Applications were only approved in cases where the predicted reductions in streamflow were within the above limits. Where permits were issued, there were further conditions attached; for example, planting was forbidden within $20-30 \mathrm{~m}$ of a riparian zone and $50 \mathrm{~m}$ of the edge of a wetland, as water use by trees had been shown to be much higher in these zones.

\subsection{Taxing environmental impacts}

South Africa's National Water Act of 1998 completely overhauled the approach to managing water resources. In terms of the new law, all water resources (including rainfall, river flow, and groundwater) are regarded as connected within a hydrological cycle, and are subject to equitable sharing by means of permit system. This permit system regulates the extraction of water from rivers, dams and boreholes. The law further recognises that certain activities will reduce runoff, and will also need to be regulated. Planting of trees for forestry purposes has been formally recognised as one such "streamflow reduction activity", and as such can only be practised where permits have been issued in terms of the water law. This approach has replaced the afforestation permit system described above.

\subsection{Requirements to manage invasive species}

South Africa's Conservation of Agricultural Resources Act (Act 43 of 1983, as amended in 2001, CARA) was promulgated in 1983. Regulations that governed the management of "declared noxious weeds" in terms of this act were put in place in 1986, when 57 alien plant species were declared as weeds. Landowners who had declared weeds on their land were required to take adequate steps to control these, and to prevent spread. This initial list did not contain any weed species that were of value, to avoid any conflict. However, following the promulgation of the National Water Act, a new set of regulations was published in the Government Gazette (Vol. 429, no. 22166 of 30 March 2001), resulting in the listing of 198 species as weeds. The revised approach classified weeds into three categories: (1) weeds of no value; (2) recognised weeds that also have commercial value; and (3) recognised weeds that have ornamental, but no commercial value. For weeds in the first category, control is required, and trade is banned. Landowners require permits to grow weeds in the second category, and are required to take steps to limit their spread; trade in these species and their products is permitted. Weeds in the third category (created to accommodate popular ornamental plants) are also subject to permits that require steps to limit their spread, but further plantings, and sale of plants and their products, is prohibited. Six species in the genus Pinus were added to the list in the second category
(Table 1). The more recent National Environment Management: Biodiversity Act (NEMBA, Act 10 of 2004) has yet to finalise its regulations, but plans to introduce similar categories that will complement those provided for by CARA. The major difference is that invasive alien plants in category 1 will be split into subcategories that recognise that some species with a very high invasive potential will need to be placed under a government-sponsored management program, in which landowners will be assisted with their legal obligations to control the spread of particularly aggressive invasive species.

\subsection{Restricting the import of new species}

The NEMBA legislation will also cover the importation of new species into the country. In terms of the regulations (not yet completed), permits for the import of species not yet present in the country will be issued subject to the completion of a risk assessment by the applicant. Unless the risk of a species becoming invasive can be shown to be low, such permits will not be issued.

\subsection{Certification of forestry operations}

Although not required by law, private and state-owned forestry companies have sought to have their operations certified in terms of acceptable environmental management practices. There are sound business reasons for this, as the sale of forestry products is often linked to such certification by potential buyers. All of the major forestry operators in South Africa (Mondi, South African Pulp and Paper Industries - SAPPI, and the government-owned South African Forest Company Limited - SAFCOL) have received certification from the Forest Stewardship Council (FSC). Obtaining certification from the FSC (the leading certification body) requires adherence to certain principles (FSC, 2000), including (under Principle 6: Environmental Impact) a requirement that "the use of exotic species shall be carefully controlled and actively monitored to avoid adverse ecological impacts". In addition, principle 10 relates to plantations, and it seeks to reduce pressures on natural forests. It promotes the use of native species rather than exotic species, and requires, among other things, that "no species shall be planted on a large scale until local trials and/or experience have shown that they ...... are not invasive, and do not have significant negative ecological impacts on other ecosystems". The FSC's principles are adapted to accommodate national standards. In the case of South Africa, FSC takes account of forestry permits, which require payment of streamflow reduction levies to compensate for adverse ecological impacts in the form of increased water use (in terms of the National Water Act, see Section 6.1), and regulations that require "all reasonable steps to be taken to curtail the spread of plants outside the demarcated areas" (in terms of CARA regulations, see Section 6.4). In reality, plantation managers are not able to curtail the spread of pines. As a result of such shortcomings, the application of FSC certification to plantations (as opposed to natural forests) is frequently criticised as counter-productive (World Rainforest Movement, 2003; Schepers, 2009).

\subsection{Payment for ecosystem services}

Because clearing projects can deliver hydrological benefits, some water utilities and municipalities raise funds through water tariffs, and use these to contract workers to control invasive alien plants in their water catchments. This approach provides access to funding for clearing programs that would be difficult to justify for other, less easily quantifiable, benefits, such as biodiversity protection (Turpie et al., 2008). 


\subsection{Proposals not yet implemented}

A number of additional measures to assist with the management of invasive conifers (and other alien species) have been debated without resolution to date. These include seed pollution taxes, requirements for clearing certificates, and biological control. The proposed tax on "seed pollution" would be similar in concept to the streamflow reduction charges that have been instated. Proponents of this approach invoked the "polluter pays" principle, arguing that the beneficiaries of forestry (plantation owners) were imposing an external cost (wind-dispersed seeds spreading invasive pines) on neighbours, who had to bear the cost of control operations or suffer the consequences. The proposal for clearing certificates called for the issuing of certificates that vouched that land had been cleared of invasive species before ownership could be transferred. Similar requirements do exist in law, for example a requirement for a "beetle certificate" that vouches that roof beams are free of borer beetles before the title deeds for a house can be transferred to a new owner. If instated, this requirement would prevent landowners from selling property if the invasive species on the property had not been cleared. The release of seed-feeding biological control agents is seen by proponents as a sustainable potential solution to the problem of invasions, given the ineffective nature of other control measures (Hoffmann et al., 2011). Proponents argue further that plantation owners could combat the "threat" (to plantations) of biological control agents in the same way that they would respond to any other insect pests (by spraying, for example). This would internalise the costs of control, in a similar way to the seed pollution taxes.

\section{Outcomes of policy interventions}

\subsection{Judicious expansion of forestry}

The afforestation permits system succeeded in limiting the impacts of afforestation on water resources. The system was in place for 22 years (1972-1995), and it significantly restricted the expansion of forestry plantations. During this time, 4300 applications were received, of which 3900, for over 1 million ha, were approved, while 400 applications for 137000 ha were refused (van der Zel, 1995). Within the afforested area, between 6 and 9\% was within the buffer zones around rivers and wetlands, and remained unafforested. Forestry companies in the private sector also began a programme of voluntary clearing of plantations established before the requirement for permits (i.e. before 1972) within these buffer zones, which resulted in the further clearing of over 12000 ha. Following the introduction of South Africa's new water law in 1996 (Section 6.3), new afforestation required a "forestry licence", which placed similar restrictions on the expansion of plantation forestry. The area under conifers peaked at 798000 ha in 1997, then declined to 660000 ha in 2009 (Forestry South Africa, 2011).

\subsection{Payment for water use}

Plantation owners now make regular payments for water use by plantations. In order to calculate payments due from growers for water use by conifer plantations, agreement had to be reached on the amount of water used by forest plantations. Understandably, the issue was contentious, and research was commissioned in an attempt to reconcile the differences in estimated water use that resulted from observation (watershed experiments) on the one hand, and modelling on the other (Gush et al., 2002). This research calculated the national average reduction in mean annual runoff attributable to plantations of pines, gums (Eucalyptus species) and wattles (Acacia species), using a modelling approach, for 843 quaternary watersheds with mean annual rainfall above $650 \mathrm{~mm}$. By assuming that all of the watersheds were fully afforested, water use was found to be about $70 \mathrm{~mm} / \mathrm{yr}$ for non-riparian settings, or 20889 million $\mathrm{m}^{3}$ annually. However, given that plantations cover only 1518138 ha (5.1\% of the 843 quaternary watersheds involved) the estimated annual water use by forestry plantations should be reduced to 1065 million $\mathrm{m}^{3}$ (Owen and van der Zel, 2000). On the basis of the above, the forest industry negotiated with government to set the estimated annual water use by plantations at $60 \mathrm{~mm}$ (Anonymous, 2002), reduced from the previously suggested $100 \mathrm{~mm}$ based on the results of watershed experiments. These calculations now form the basis for ongoing payments for streamflow reduction by plantations. In 2005, foresters paid 32c/ $\mathrm{m}^{3}$ for estimated streamflow reduction, compared to an estimated value for water of between $\mathrm{R} 1.79$ and $\mathrm{R} 3.62 / \mathrm{m}^{3}$, suggesting that the forest industry received a substantial subsidy (Tewari, 2005).

\subsection{Privatization of plantation forestry}

Plantation-based forestry was originally a government undertaking, but the private sector has a long history in the South African forestry sector (Olivier, 2009). The private sector expanded significantly in the second half of the 20th century, and developed largely as a wood chip and pulp export business (Louw, 2004a). By 1975, privately-owned forest plantations made up over $70 \%$ of all plantations (Louw, 2004a). In 1985, government took the first steps towards privatization of its plantation forestry operations through the establishment of a "trading account" which tracked all costs and income from plantations, and sought to cover costs from the sale of forest products. In 1990, the South African Forestry Company Limited (SAFCOL) was established as a further step towards possible privatization, and an Act was passed to provide for the privatization of Government plantations through SAFCOL in 1992 (Louw, 2004b). By 2003, most of these plantations were taken over by the private sector. However, the plantations in the southwestern (fynbos) regions of the country failed to attract any bidders, as they were economically unattractive (Louw, 2006). The future of these plantations (mainly pines) is uncertain (Kraaij et al., 2011).

\subsection{Clearing invasive conifers}

Co-ordinated attempts to systematically clear invasive pines from watershed areas began in the fynbos areas of South Africa in the early 1970s. For example, an average of 35000 ha of mountain land was cleared of invasive pines and hakeas each year between 1970 and 1974 (Fenn, 1980). The momentum was lost in the 1980s, and it was only with the establishment of a new democraticallyelected government in South Africa in 1994 that large-scale control operations were resumed under the auspices of the Working for Water programme (van Wilgen et al., 1998; van Wilgen, 2009; van Wilgen et al., 2011a). This programme was established to meet the dual aims of clearing invasive alien plants and creating employment among the rural poor. Its establishment was based on studies that showed the impacts of alien plants on the loss of water resources, as well as on the large numbers of jobs that could be created in the clearance of invasive alien plants. The ability to create jobs was and remains a prime factor that enabled ongoing political support.

Working for Water has addressed the control of invasive pines since 1995 , especially in the fynbos biome. However, there is no indication that the extent of invasion has decreased in the fynbos biome. Unpublished data from Working for Water show that control projects have reached only a part of the invaded area, and invasive pines remain prominent. Marais et al. (2004) estimated that about 3500 ha (100\% canopy cover equivalent) of invasive 
pines had been cleared, and subjected to the necessary follow-up treatments annually. At this rate, and assuming no spread (an unrealistic assumption), Marais et al. (2004) estimated that it would take 22 years to clear existing stands of invasive pines. One study in the eastern fynbos biome (Moeller, 2010) estimated that the cover of invasive pines had more than doubled (from 13.4 to $28.7 \%$ ) between 1986 and 2007. In the absence of biological control solutions, the rugged and inaccessible mountain areas remain vulnerable to invasion by pines, which represent the most significant threat to the integrity of fynbos ecosystems (Hoffmann et al., 2011; Kraaij et al., 2011)

\subsection{Attitudes towards conifers}

Trees and forests are generally viewed by people as beneficial, and the deliberate removal of plantations (to prevent further spread) or the clearing of invasive pines often attracts considerable criticism, despite strong evidence for the impacts of these trees, and the benefits of clearing. For example, in the Table Mountain National Park (which lies within the city of Cape Town), pine plantations are being removed based on their invasive properties and the negative impacts of invasion. Those against this removal cite the value of pine plantations for recreation, aesthetic concerns, the (perceived) unattractive nature of the treeless natural vegetation, and the (incorrect) belief that trees bring additional rainfall (van Wilgen, in press). Despite opposition, the policy promoting alien plant removal has remained in place, and considerable progress has been made towards clearing pine plantations and invasive populations from the Table Mountain National Park. The reasons for this conservation success lie in political support. The support is largely due to the employment opportunities offered by clearing projects, but is strengthened by sufficient scientific evidence of impacts (see, for example, van Wilgen et al., 2001; Görgens and van Wilgen, 2004; Richardson and van Wilgen, 2004; Le Maitre et al., 2011).

\section{Future challenges}

\subsection{Pine-based plantation forestry}

Plantation-based forestry has remained an attractive land-use option because of the ongoing demand for building timber, and the contribution of the forest industry to job creation and the economy in general. Pine-based plantation forestry nonetheless faces significant challenges in South Africa. While this form of landuse produces reasonable returns on investment in the northern parts of the country (summer-rainfall regions where extensive plantations of $P$. patula have been established in native grasslands), this is not the case for parts of the southern area of the country. It is in this area that plantations were often established on poor sites, and they do not yield economic returns that would justify ongoing management costs (Kraaij et al., 2011). The formal recognition of impacts associated with plantation forestry in legislation, in the form of imposed payments to offset water losses, and requirements to deal with trees that become invasive, place further pressures on the industry. In addition, forest plantations have been established throughout the country in areas subject to regular wildfires, which increasingly inflict serious damage to plantations, leading to substantial financial losses. Damage to plantations by wildfires over the past two decades has increased steadily, and recently dramatically (Fig. 2), although the reasons for this are not clear. Plantations of conifers also face the threat of serious outbreaks of pathogens although these have not yet had a significant effect; as a result, forestry companies are being urged to establish breeding and selection programmes to identify disease-tolerant planting stock

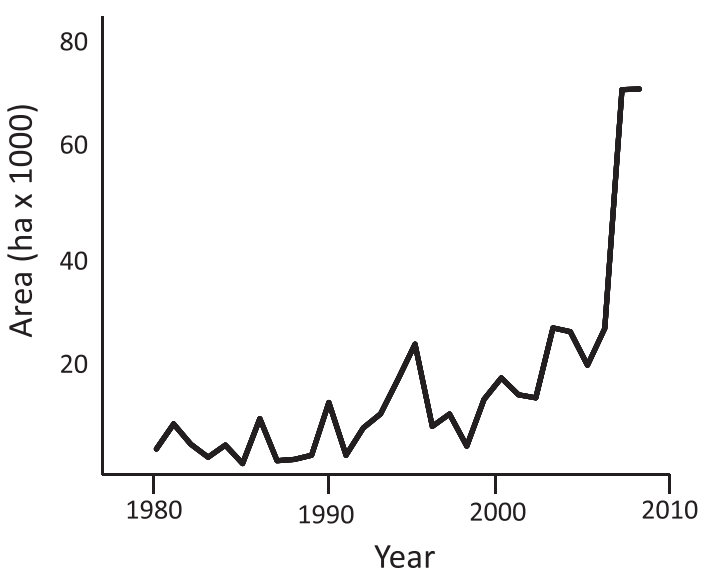

Fig. 2. Areas of plantation forestry subjected to wildfires over the past three decades in South Africa (data from Forestry South Africa, 2011).

(Roux et al., 2005). Certification by the Forestry Stewardship Council can also further restrict the options available to foresters. These include discouraging the use of genetically-modified trees (which could both improve disease tolerance and possibly reduce invasive potential through the breeding of sterile cultivars) and the use of pesticides (which could potentially be used to counter the effects of any biological control agents).

\subsection{Invasion of natural landscapes}

Of the 57 species listed in Table 1, at least five are widespread invaders, and several more have the potential to become invasive. Much suitable habitat remains (Rouget et al., 2004), suggesting that invasions will continue to spread if current conditions prevail, despite ongoing attempts to clear them. This is particularly the case in fynbos shrublands, because the rugged and inaccessible nature of the terrain (Fig. 1D) prevents effective control operations, and the prevailing fire regime promotes the spread and densification of pines (van Wilgen et al., 2010). The impacts of invasions on water resources and other ecosystem services can therefore be expected to grow. Despite the varied and often novel and innovative approaches adopted to enhance the prospects of gaining control of conifer invasions, the prognosis under a scenario of "business-as-usual" is not encouraging. Legal instruments that require landowners and growers to take effective steps against invasions have either remained unenforced, or have been ignored with impunity. Attempts to address the problem through the introduction of biological control agents have been suspended due to concerns about potential harm to the forest industry. Unprofitable plantations have been abandoned under the policies of privatization, and handed over to cash-strapped conservation agencies which do not have the resources needed to rehabilitate these areas (Kraaij et al., 2011). There appear to be no viable options for the control of invasive pines in remote and rugged mountain watershed areas, where the range and density of these plants continues to increase. Public resistance to clearing operations in more accessible areas, where clearing is practically feasible, further impedes progress. Clearing efforts to date have proceeded under what has been termed a "strategy of hope" (van Wilgen et al., 2011b), where available (but inadequate) resources are directed at pockets of the problem in an un-coordinated, without objective prioritisation, leading to ineffective control.

\subsection{Plantation forestry and the new bioeconomy}

Socio-political developments and escalating environmental concerns in South Africa, along with global economic and 
Table 2

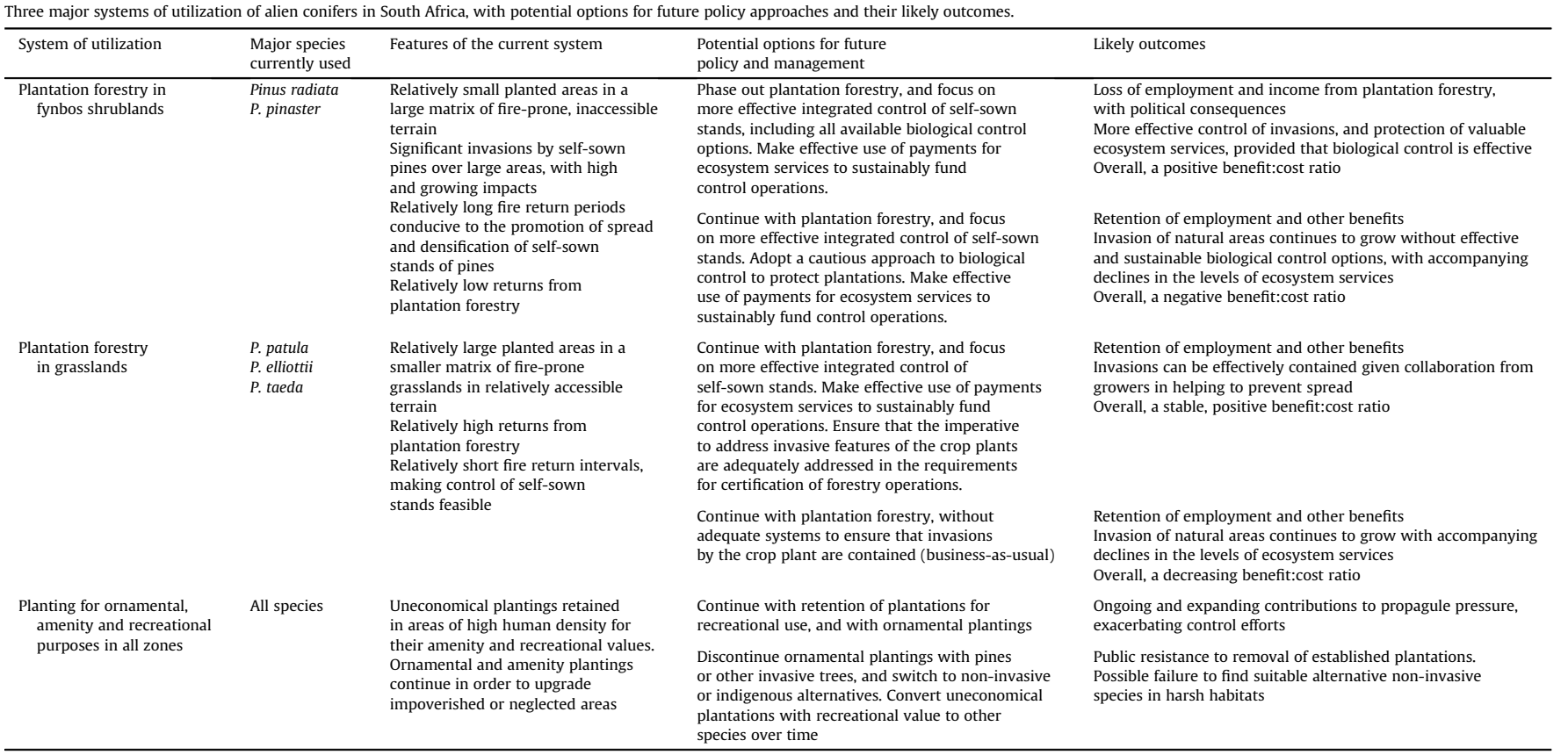


environmental issues, demand innovative approaches for managing the new bioeconomy to ensure sustainable delivery of products such as pulp and timber, while simultaneously ensuring the long-term sustainability of natural capital and ecosystem functioning. Increasing demands for products and services from alien plants (via plantation forestry, agroforestry, horticulture, and biofuel production) is leading to escalating conflicts relating to land-use and conservation. The situation calls for innovative approaches to multi-purpose landuse planning that are closely aligned with regional and national conservation plans (Blanchard et al., 2011).

South Africa has already taken bold steps by attempting to address the problem of highly invasive species that are also important commercial crops. It is the only country to have introduced legislation to address the management of such species by creating different categories of weeds, to have introduced biological control for important alien forestry species (in the genus Acacia, see Impson et al., 2009, van Wilgen et al., 2011b), and to have imposed environmental taxes on such crops. These policy interventions may not yet have been entirely successful, but the experiment is ongoing. Reversing the trends of increasing invasion and impact, while protecting benefits, is a daunting challenge, but several as yet untested options remain.

This review suggests that conifer management in South Africa can be addressed according to three distinct systems of utilization (Table 2). The first relates to pine plantation forestry in the fynbos regions of the country, which operates in an environment containing large tracts of inaccessible, rugged terrain of exceptional biological diversity. These areas are vital for water production as well as conservation. Regular fires drive ongoing invasion, and are a significant threat to plantations as well. Many of the forestry plantations are economically unsustainable. Resource economic studies (for example De Wit et al., 2001; De Lange and van Wilgen, 2010) suggest that the benefits gained from commercial forestry undertakings are often considerably smaller than the impacts from related invasions of the crop species concerned.

The effectiveness of control operations in fynbos areas could arguably be improved in a number of ways. These include generating substantially higher levels of funding for control operations through schemes that utilize payments for ecosystem services, resuming and expanding the search for suitable biological control agents, prioritizing areas for control to ensure that adequate funding gets channelled to areas where it is most needed and will be most effective, raising awareness and understanding through targeted information campaigns, and combining available control techniques to maximise the chances of their impact. A successful precedent exists for the use of seed-feeding biological control agents on commercially-important trees (Impson et al., 2009), and this needs to be aggressively pursued as it provides arguably the only control option that will be effective and sustainable over the long-term. In addition, the adoption of appropriate decisionsupport methods could judiciously reduce the logistical problems that face alien plant control managers (Roura-Pascual et al., 2009). Maintaining the plantations for arguably limited benefit would nonetheless be accompanied by ongoing invasion and the erosion of very important ecosystem benefits, to the overall detriment of other development opportunities in the region. Phasing out plantation forestry would improve the chances of sustainable control of invasions substantially, but would be politically difficult given the prevailing socio-economic needs for employment. Nonetheless, this option would almost certainly deliver higher overall benefits, and needs to be seriously considered.

The second system relates to pine plantation forestry in the grassland regions of the country, which operates in an environment in which the control of invasions is made feasible by the relative accessibility of the terrain, and by a fire regime that does not drive the spread of self-sown pines as aggressively as it does in the fynbos. In addition, pine-based forestry in these areas is generally economically viable. Here, policy-makers should consider options that would encourage a responsible approach to the problem, by allowing plantation forestry to continue, but encouraging appropriate contributions to control operations by both growers and beneficiaries of ecosystem services.

The third system relates to the broad non-commercial utilization of all pine species as ornamental and utility trees, and to the retention of uneconomical plantations where these exist in areas of high human density and are frequently used for recreational purposes. The continued utilization of invasive conifers for these purposes will exacerbate the problem of control by providing a ready source of seeds for the invasion or re-invasion of nearby ecosystems, thus eroding ecosystem services and increasing the costs of control. An alternative exists through the use of noninvasive or indigenous tree species, but this would require replacement of existing trees which would both be unpopular and would take several decades due to the slow growth of replacement trees. We have attempted to illustrate some of the more obvious choices that exist, and the likely outcomes that these would have. In our opinion, the choice should favour the options that deliver the largest benefits, although this will require strong political will and courage if it is to be implemented. Failure to do so, on the other hand, will in all likelihood result in a degraded environment far less capable of delivering ongoing and vital services on a sustainable basis.

\section{Acknowledgements}

We acknowledge support from the Working for Water programme and the DST-NRF Centre for Invasion Biology, partly through their collaborative research project on "Research in support of the management of invasive plant species in South Africa" DMR acknowledges funding from the National Research Foundation.

\section{References}

Allen, D.G., Harrison, J.A., Navarro, R.A., van Wilgen, B.W., Thompson, M.W. 1997. The impact of commercial afforestation on bird populations in Mpumalanga province, South Africa - insights from bird atlas data. Biological Conservation 79, 173-185.

Anonymous, May/June 2002. DWAF's rain management charges: the cost to you. SA Forestry, 11-13.

Anonymous, 2009. National Greenhouse Gas Inventory South Africa: 1990-2000. Department of Environmental Affairs and Tourism, Pretoria.

Blanchard, R., Richardson, D.M., O'Farrell, P., von Maltitz, G.P., 2011. Biofuels and biodiversity in South Africa. South African Journal of Science 107. doi:10.4102/ sajs.v107i5/6.186.

Bond, P., Goldblatt, P., 1984. Plants of the Cape Flora: a descriptive catalogue. Journal of South African Botany 13 (Suppl.).

Bosch, J.M., Hewlett, J.D., 1982. A review of catchment experiments to determine the effects of vegetation changes on water yield and evapotranspiration. Journal of Hydrology 55, 2-23.

Bosch, J.M., 1979. Treatment effects of annual and dry period streamflow at Cathedral Peak. South African Forestry Journal 108, 29-38.

De Lange, W.J., van Wilgen, B.W., 2010. An economic assessment of the contribution of weed biological control to the management of invasive alien plants and to the protection of ecosystem services in South Africa. Biological Invasions 12 $4113-4124$

De Wit, M.P., Crookes, D.J., van Wilgen, B.W., 2001. Conflicts of interest in environmental management: estimating the costs and benefits of a tree invasion. Biological Invasions 3, 167-178.

Dye, P.J., Olbrich, B.W., Everson, C.S., 1995. The Water Use of Plantation Forests and Montane Grassland in Summer Rainfall Forestry Regions of South Africa. Proceedings of the Seventh South African National Hydrological Symposium. Institute for Water Research, Grahamstown.

Dye, P... 1988. How plants make water flow uphill. African Wildlife 42, 7-8.

Dye, P.J., 1996. Climate, forest and streamflow relationships in South African afforested catchments. Commonwealth Forestry Review 75, 31-38. 
FAO, 2010. Global Forest Resources Assessment 2010. Forestry Paper 163. Food and Agriculture Organization of the United Nations, Rome.

Fenn, J.A., 1980. Control of Hakea in the western Cape. In: Neser, S., Cairns, A.L.P. (Eds.), Proceedings of the Third National Weeds Conference of South Africa. Balkema, Cape Town, pp. 167-173.

Forestry South Africa, 2011. http://www.forestry.co.za/, (accessed 28.04.11.).

FSC, 2000. FSC Principles and Criteria for Forest Stewardship. Document 1.2, Revised February 2000. Forest Stewardship Council, United Kingdom.

Fugler, S.R., 1979. Some aspects of the autecology of three Hakea species in the Cape Province, South Africa. MSc Thesis, University of Cape Town.

Görgens, A.H.M., van Wilgen, B.W., 2004. Invasive alien plants and water resources in South Africa: current understanding, predictive ability and research challenges. South African Journal of Science 100, 27-33.

Grut, M., 1965. Forestry and Forest Industry in South Africa. Balkema, Cape Town.

Gush, M., Scott, D., Jewitt, G., Schulze, R., Lumsden, T., Hallowes, L., Görgens, A.H.M., 2002. Estimation of Streamflow Reductions Resulting from Commercial Afforestation in South Africa. Report TT 173/02. Water Research Commission, Pretoria.

Henderson, L., 2001. Alien Weeds and Invasive Plants: A Complete Guide to Declared Weeds and Invaders in South Africa. Agricultural Research Council, Pretoria.

Hoffmann, J.H., Moran, V.C., van Wilgen, B.W., 2011. Prospects for biological control of invasive Pinus species (Pinaceae) in South Africa. African Entomology 19, 393-401.

Impson, F.A.C., Hoffmann, J.H., Kleinjan, C., 2009. Biological control of Australian Acacia species. In: Muniappan, R., Reddy, G.V.P., Raman, A. (Eds.), Biological Control of Tropical Weeds Using Arthropods. Cambridge University Press, Cambridge, pp. 38-62.

Jackson, R.B., Jobbagy, E.G., Avissar, R., Baidya, R.S., Barrett, D.J., Cook, C.W., Farley, K.A., Le Maitre, D.C., McCarl, B.A., Murray, B.C., 2005. Trading water for carbon with biological carbon sequestration. Science 310, 1944-1947.

Johnson, S.D., 1992. Plant-animal relationships. In: Cowling, R.M. (Ed.), The Ecology of Fynbos: Nutrients, Fire and Diversity. Oxford University Press, Cape Town, pp. 175-205

Kotzé, J.D.F., Beukes, B.H., van den Berg, E.C., Newby, T.S., 2010. National Invasive Alien Plant Survey. Report Number GW/A/2010/21. Agricultural Research Council, Pretoria.

Kraaij, T., Cowling, R.M., van Wilgen, B.W., 2011. Past approaches and future challenges to the management of fire and invasive alien plants in the new Garden Route National Park. South African Journal of Science 107 (9/10), 11. doi:10.4102/sajs.v107i9/10.633. Art. \#633.

Kruger, F.J., 1977. Invasive woody plants in Cape fynbos with special reference to the biology and control of Pinus pinaster. In: Proceedings of the Second National Weeds Conference of South Africa, Stellenbosch, pp. 57-74

Le Maitre, D.C., van Wilgen, B.W., Chapman, R.A., McKelly, D., 1996. Invasive plants and water resources in the Western Cape Province, South Africa: modelling the consequences of a lack of management. Journal of Applied Ecology 33, 161-172.

Le Maitre, D.C., Versfeld, D.B., Chapman, R.A., 2000. The impact of invading alien plants on surface water resources in South Africa: a preliminary assessment. Water SA 26, 397-408.

Le Maitre, D.C., van Wilgen, B.W., Gelderblom, C.M., Bailey, C., Chapman, R.A., Nel, J.A., 2002. Invasive alien trees and water resources in South Africa: case studies of the costs and benefits of management. Forest Ecology and Management $160,143-159$.

Le Maitre, D.C., Gaertner, M., Marchante, E.M., Ens, E.-J., Holmes, P.M., Pauchard, A., O'Farrell, P.J., Rogers, A.M., Blanchard, R., Blignaut, J., Richardson, D.M., 2011. Impacts of invasive Australian acacias: implications for management and restoration. Diversity \& Distributions 17, 1015-1029.

Lennox, C.L., Hoffmann, J.H., Coutinho, T.A., Roques, A., 2009. A threat of exacerbating the spread of pitch canker precludes further consideration of a cone weevil, Pissodes validirostris, for biological control of invasive pines in South Africa. Biological Control 50, 179-184.

Levin, S.A., 2002. Complex adaptive systems: exploring the known, the unknown and the unknowable. Bulletin of the American Mathematical Society 40, 3-19.

Lister, M.H., 1959. A forgotten experiment in tree planting. Journal of the South African Forestry Association 33, 59-66.

Loock, E.E.M., 1950. The Pines of Mexico and British Honduras. Bulletin 35. South African Department of Agriculture and Forestry, Pretoria.

Louw, W.J.A., 2004a. General history of the South African forest industry: 1975 to 1990. South African Forestry Journal 200, 77-86.

Louw, W.J.A., 2004b. General history of the South African forest industry: 1991 to 2002. South African Forestry Journal 201, 65-76.

Louw, W.J.A., 2006. General history of the South African forest industry: 2003 to 2006. South African Forestry Journal 208, 79-88.

Macdonald, I.A.W., Kruger, F.J., Ferrar, A.A., 1986. The Ecology and Management of Biological Invasions in Southern Africa. Oxford University Press, Cape Town.

Marais, C., van Wilgen, B.W., Stevens, D., 2004. The clearing of invasive alien plants in South Africa: a preliminary assessment of costs and progress. South African Journal of Science 100, 97-103.

Millennium Ecosystem Assessment, 2005. Ecosystems and Human Wellbeing: Synthesis. Island Press, Washington, DC.

Moeller, J., 2010. Spatial analysis of pine tree invasion in the Tsitsikamma region, Eastern Cape, South Africa: A pilot study. Honours dissertation, Department of Geography, Rhodes University, Grahamstown.

Moran, V.C., Hoffmann, J.H., Donnelly, D., Zimmermann, H.G., van Wilgen, B.W., 2000. Biological control of alien invasive pine trees (Pinus species) in South
Africa. In: Spencer, N.R. (Ed.), Proceedings of the Xth International Symposium on Biological Control of Weeds. Montana State University, Bozeman, Montana, pp. 941-953.

Olivier, W., 2009. There is Honey in the Forest: The History of Forestry in South Africa. Southern African Institute of Forestry, Pretoria.

Owen, D.L., van der Zel, D.W., 2000. Trees, forests and plantations in southern Africa. In: Owen, D.L. (Ed.), South African Forestry Handbook 2000. Southern African Forestry Institute, Menlo Park.

Poynton, R.J., 1979. Tree Planting in Southern Africa. In: The Pines, vol. 1. Department of Forestry, Pretoria.

Poynton, R.J., 2009. Tree Planting in Southern Africa. In: Other Genera, vol. 3. Department of Agriculture, Forestry and Fisheries, Pretoria.

Pryke, J.S., Samways, M.J., 2009. Recovery of invertebrate diversity in a rehabilitated city landscape mosaic in the heart of a biodiversity hotspot. Landscape and Urban Planning 93, 54-62.

Raimondo, D., von Staden, L., Foden, W., Victor, J.E., Helme, N.A., Turner, R.C., Kamundi, D.A., Manyama, P.A., 2009. Red List of South African Plants 2009. Strelitzia 25. South African National Biodiversity Institute, Pretoria.

Rejmánek, M., Richardson, D.M., 1996. What attributes make some plant species more invasive? Ecology 77, 1655-1661.

Richardson, D.M., Higgins, S.I., 1998. Pines as invaders in the southern hemisphere. In: Richardson, D.M. (Ed.), Ecology and Biogeography of Pinus. Cambridge University Press, Cambridge, pp. 450-473.

Richardson, D.M., Rejmánek, M., 2004. Invasive conifers: a global survey and predictive framework. Diversity and Distributions 10, 321-331.

Richardson, D.M., van Wilgen, B.W., 2004. Invasive alien plants in South Africa: how well do we understand the ecological impacts? South African Journal of Science 100, 45-52.

Richardson, D.M., Macdonald, I.A.W., Hoffmann, J.H., Henderson, L., 1997. Alien plant invasions. In: Cowling, R.M., Richardson, D.M., Pierce, S.M. (Eds.), Vegetation of Southern Africa. Cambridge University Press, Cambridge, pp. 535-570.

Richardson, D.M., Cambray, J.A., Chapman, R.A., Dean, W.R.J., Griffiths, C.L., Le Maitre, D.C., Newton, D.J., Winstanley, T.J., 2003. Vectors and pathways of biological invasions in South Africa - Past, future and present. In: Ruiz, G., Carlton, J. (Eds.), Invasive Species: Vectors and Management Strategies. Island Press, Washington, D.C, pp. 292-349.

Richardson, D.M., Rundel, P.W., Jackson, S.T., Teskey, R.O., Aronson, J., Bytnerowicz, A., Wingfield, M.J., Procheş, S., 2007. Human impacts in pine forests: past, present and future. Annual Reviews of Ecology, Evolution, and Systematics 38, 275-297.

Richardson, D.M., 1989. The ecology of invasions by Pinus (Pinaceae) and Hakea (Proteaceae) species, with special emphasis on patterns, processes and consequences of invasion in mountain fynbos of the southwestern Cape Province, South Africa. PhD Thesis, University of Cape Town.

Richardson, D.M., 1998. Forestry trees as invasive aliens. Conservation Biology 12, $18-26$.

Richardson, D.M., 2006. Pinus: a model group for unlocking the secrets of alien plant invasions? Preslia 78, 375-388.

Rouget, M., Richardson, D.M., Cowling, R.M., Lloyd, J.W., Lombard, A.T., 2003. Current patterns of habitat transformation and future threats to biodiversity in the Cape Floristic Region, South Africa. Biological Conservation 112, 63-85.

Rouget, M., Richardson, D.M., Nel, J.L., Le Maitre, D.C., Egoh, B., Mgidi, T., 2004. Mapping the potential spread of major plant invaders in South Africa using climatic suitability. Diversity and Distributions 10, 475-484

Roura-Pascual, N., Richardson, D.M., Krug, R., Brown, A., Chapman, R.A., Forsyth, G.G. Le Maitre, D.C., Robertson, M.P. Stafford, L, van Wilgen, B.W. Wessels, N., 2009. Ecology and management of alien plant invasions in South African fynbos: accommodating key complexities in objective decision-making. Biological Conservation 142, 1595-1604.

Roux, J., Meke, G., Kanyi, B., Mwangi, L., Mbaga, A., Hunter, G.C., Nakabonge, G., Heath, R.N., Wingfield, M.J., 2005. Diseases of plantation forestry trees in eastern and southern Africa. South African Journal of Science 101, 409-413.

Samways, M.J., Taylor, S., Tarboton, W., 2005. Extinction reprieve following alien removal. Conservation Biology 19, 1329-1330.

Schepers, D.H., 2009. Challenges to legitimacy at the forest stewardship council. Journal of Business Ethics 92, 279-290.

Scott, D.F., van Wyk, D.B., 1990. The effects of wildfire on soil wettability and hydrological behaviour of an afforested catchment. Journal of Hydrology 121, 239-256.

Scott, D.F., Versfeld, D.B., Lesch, W., 1998. Erosion and sediment yield in relation to afforestation and fire in the mountains of the Western Cape Province, South Africa. South African Geographical Journal 80, 52-59.

Simberloff, D., Nuñez, M., Ledgard, N.J., Pauchard, A., Richardson, D.M., Sarasola, M., van Wilgen, B.W., Zalba, S.M., Zenni, R.D., Bustamante, R., Peña, E., Ziller, S.R., 2010. Spread and impact of introduced conifers in South America: lessons from other southern hemisphere regions. Austral Ecology 35, 489-504.

Smith, R.E., Scott, D.F., 1992. Simple Empirical Models to Predict Reductions in Annual and Low Flows Resulting from Afforestation. Report FOR-DEA 465. CSIR Division of Forest Science and Technology, Pretoria.

Stirton, C.H., 1978. Plant Invaders, Beautiful but Dangerous. Department of Nature and Environmental Conservation, Cape Town

Tewari, D.D., 2005. Should commercial forestry in South Africa pay for water? Valuing water and its contribution to the industry. Water SA 31, 319-326.

Turpie, J.K., Marais, C., Blignaut, J.N., 2008. The Working for Water programme: evolution of a payments for ecosystem services mechanism that addresses both poverty and ecosystem service delivery in South Africa. Ecological Economics 65, 788-798. 
van der Zel, D.W., 1995. Accomplishments and dynamics of the South African afforestation permit system. South African Forestry Journal 172, 49-58.

van Lill, W.S., Kruger, F.J., van Wyk, D.B., 1980. The effect of afforestation with Eucalyptus grandis Hill ex Maiden and Pinus patula Schlecht. Et. Cham. on streamflow from experimental catchments at Mokubalaan, Transvaal. Journal of Hydrology 48, 107-118.

van Wilgen, B.W., Richardson, D.M., 1985. The effect of alien shrub invasions on vegetation structure and fire behaviour in South African fynbos shrublands: a simulation study. Journal of Applied Ecology 22, 955-966.

van Wilgen, B.W., Scholes, R.J., 1997. The vegetation and fire regimes of southern hemisphere Africa. In: van Wilgen, B.W., Andreae, M.O., Goldammer, G.J., Lindesay, J.A. (Eds.), Fire in Southern African Savannas: Ecological and Atmospheric Perspectives. Wits University Press, Johannesburg, pp. 27-46.

van Wilgen, B.W., Scott, D.F., 2001. Managing fires on the Cape Peninsula: dealing with the inevitable. Journal of Mediterranean Ecology 2, 197-208.

van Wilgen, B.W., Cowling, R.M., Burgers, C.J., 1996. Valuation of ecosystem services. A case study from South African fynbos ecosystems. BioScience 46, 184-189.

van Wilgen, B.W., Le Maitre, D.C., Cowling, R.M., 1998. Ecosystem services, efficiency, sustainability and equity: South Africa's Working for Water programme. Trends in Ecology and Evolution 13, 378.

van Wilgen, B.W., Richardson, D.M., Le Maitre, D.C., Marais, C., Magadlela, D., 2001 The economic consequences of alien plant invasions: examples of impacts and approaches to sustainable management in South Africa. Environment, Development and Sustainability 3, 145-168.

van Wilgen, B.W., Le Maitre, D.C., Reyers, B., Richardson, D.M., Schonegevel, L., 2008. Invasive alien plants and the delivery of services from South African ecosystems: a preliminary assessment. Journal of Environmental Management 89, 336-349.

van Wilgen, B.W., Forsyth, G.G., de Klerk, H., Das, S., Khuluse, S., Schmitz, P., 2010. Fire management in Mediterranean-climate shrublands: a case study from the Cape fynbos, South Africa. Journal of Applied Ecology 47, 631-638.

van Wilgen, B.W., Khan, A., Marais, C., 2011a. Changing perspectives on managing biological invasions: insights from South Africa and the Working for Water programme. In: Richardson, D.M. (Ed.), Fifty Years of Invasion Ecology. The legacy of Charles Elton.Wiley-Blackwell, Oxford, pp. 377-393.

van Wilgen, B.W., Dyer, C., Hoffmann, J.H., Ivey, P., Le Maitre, D.C., Richardson, D.M. Rouget, M., Wannenburgh, A., Wilson, J.R.U., 2011b. National-scale strategic approaches for managing introduced plants: insights from Australian acacias in South Africa. Diversity and Distributions 17, 1060-1075.

van Wilgen, B.W., 1988. Fynbos terrestrial ecosystems. In: Macdonald, I.A.W. Crawford, R.J.M. (Eds.), Long-term Data Series Relating to Southern Africa's Renewable Natural Resources. South African National Scientific Programmes Report No. 157. Foundation for Research Development, Pretoria, pp. 216-236.

van Wilgen, B.W., 2009. The evolution of fire and invasive alien plant management practices in fynbos. South African Journal of Science 105, 335-342.

van Wilgen, B.W., in press. Evidence, perceptions and trade-offs associated with invasive alien plant control in the Table Mountain National Park, South Africa. Ecology and Society 17(1), 8.

van Wyk, D.B., 1985. The effects of catchment management on sediment and nutrient exports in the Natal Drakensberg. In: Schulze, R.E. (Ed.), Proceedings of the 2nd South African National Hydrological Symposium. University of Natal, Pietermaritzburg, pp. 266-274.

van Wyk, D.B., 1987. Some effects of afforestation on streamflow in the Western Cape province, South Africa. Water SA 14, 31-36.

Versfeld, D.B., van Wilgen, B.W., 1986. Impacts of woody aliens on ecosystem properties. In: Macdonald, I.A.W., Kruger, F.J., Ferrar, A.A. (Eds.), The Ecology and Control of Biological Invasions in South Africa. Oxford University Press, Cape Town, pp. 239-246.

Wicht, C.L., 1939. Forest influence research technique at Jonkershoek. Journal of the South African Forestry Association 3, 65-80.

World Rainforest Movement, 2003. Certifying the Uncertifiable: FSC Certification of Tree Plantations in Thailand and Brazil. World Rainforest Movement, Montevideo, Uraguay.

Wright, JA DiNicola, A Gaitan, E. 2000. Latin American forest plantations: opportunities for carbon sequestration, economic development, and financial returns. Journal of Forestry 98, 20-23. 